\title{
PENGARUH KOMPOSISI PENGELOLA PERUSAHAAN TERHADAP KINERJA KEUANGAN \\ (Studi pada Badan Usaha Milik Negara yang Terdaftar di Bursa Efek Indonesia)
}

\author{
Meyzia Irestia Putri \\ Risal Rinofah \\ Mujino \\ Universitas Sarjanawiyata Tamansiswa \\ mujino@ustjogja.ac.id
}

\begin{abstract}
This study aims to examine the effect of the composition of company managers on financial performance. The composition of the company management is proxied by using the number of independent commissioners, the board of commissioners, and the board of directors. The company's financial performance is measured by profitability ratios, namely Return On Investment (ROI). The population in this study are companies that are included in the State Owned Enterprises (SOEs) listed on the Indonesia Stock Exchange (BEI) in 2010-2018. The sample selection technique used purposive sampling method. Based on the criteria that have been determined, 8 companies chosen as sample. The type of data used are secondary data in the form of annual reports and financial statements. Data analysis technique used multiple linear regression analysis. The results of this study showed that simultaneously, independent commissioner, board of commissioner, and board of directors have a significant effect on ROI. Partially, independent commissioner, audit committee, board of commissioner, and board of directors has positive and significant effect on ROI. While another Good Corporate Governance proxy, which are the audit committee and board of directors have a positive effect but not significant on ROI.
\end{abstract}

Keywords: Corporate Governance; Company Management Composition; Financial Performance; Profitability.

\section{PENDAHULUAN}

Pada saat ini, praktik mengenai tata kelola sudah banyak dilakukan oleh perusahaan di Indonesia (Riandi, 2011). Lebih lanjut Riandi (2011), menyebutkan bahwa penerapan tata kelola yang baik dapat meningkatkan nilai perusahaan yaitu dengan cara meningkatkan kinerja keuangan, menurunkan risiko dan meningkatkan kepercayaan investor. Studi yang dilakukan Sarafina (2017) menjelaskan bahwa kinerja keuangan adalah patokan utama yang digunakan dalam menilai baik dan tidaknya kinerja pada suatu perusahaan. Indikator yang biasanya digunakan dalam menilai kinerja keuangan pada suatu perusahaan yaitu dengan menggunakan rasio keuangan (Sarafina, 2017).

Rasio keuangan yang umum digunakan adalah rasio likuiditas, solvabilitas, dan profitabilitas (Sarafina, 2017). Studi yang dilakukan oleh Utami (2012) menyebutkan bahwa tujuan dari 
adanya prinsip dasar tata kelola, yaitu memberikan kemajuan terhadap kinerja perusahaan, salah satunya adalah profitabilitas. Profitabilitas merupakan dasar penilaian yang digunakan untuk menilai kondisi perusahaan, sehingga dibutuhkan alat analisis menggunakan rasio profitabilitas (Rimardhani, 2016).

Rasio yang digunakan untuk menghitung profitabilitas yaitu dengan menggunakan Return On Invesment (ROI) merupakan rasio keuangan untuk mengukur kemampuan dari perusahaan dalam menghasilkan suatu keuntungan yang nantinya akan digunakan dalam menutup investasi yang dikeluarkan perusahaan (Paradita, 2009).

Pelaksanaan tata kelola sudah menjadi kebutuhan bagi perusahaan, sehingga menjadi keharusan bagi perusahaan untuk menerapkan dan melaksanakannya sehingga tujuan perusahaan bisa tercapai (Utami, 2012). Bagi BUMN penerapan tata kelola merupakan kewajiban dalam upaya mewujudkan konsep tata kelola pada suatu perusahaan.

Penelitian mengenai tata kelola perusahaan yang baik telah banyak dilakukan di Indonesia. Beberapa peneliti sebelumnya melakukan penelitian mengenai hubungan tata kelola perusahaan yang baik dengan kinerja keuangan, namun hasil yang diperoleh oleh beberapa peneliti sebelumnya masih belum konsisten. Studi yang dilakukan Riandi (2011), menemukan bahwa penerapan tata kelola memiliki pengaruh yang bervariatif terhadap profitabilitas perusahaan, hal tersebut tergantung dari alat ukur apa yang digunakan peneliti dalam melakukan penelitian.

Penelitian yang dilakukan Ferdiana (2012) menunjukkan bahwa tata kelola yang diukur menggunakan rasio profitabilitas berpengaruh terhadap kinerja keuangan. Penelitian yang dilakukan Utami (2012) menyatakan bahwa penerapan tata kelola berpengaruh terhadap Net Profit
Margin (NPM), Return On Equity (ROE), dan Earning Per Share (EPS) tidak berpengaruh terhadap Return On Asset (ROA).

Studi yang dilakukan oleh Prasinta (2012) menunjukkan bahwa kinerja keuangan perusahaan dapat dipengaruhi oleh tata kelola perusahaan yang baik. Harapannya dengan adanya penerapan tata kelola perusahaan tersebut kinerja keuangan akan meningkat, mengurangi terjadinya risiko yang bisa merugikan perusahaan dan mencegah terjadinya kecurangan (Fitria, 2018).

Penelitian ini merupakan pengembangan dari penelitian sebelumnya yang dilakukan oleh Rimardhani (2016), Sarafina (2017), Putri (2018). Perbedaan penelitian ini dengan penelitian sebelumnya terletak pada variabel yang digunakan. Dalam penelitian ini untuk mengukur kinerja keuangan menggunakan Return On Investment (ROI) dan untuk mengukur komposisi pengelola perusahaan menggunakan jumlah komisaris independen, dewan komisaris, dan dewan direksi.

Peneliti ini menganalisis mengenai pengaruh komposisi pengelola perusahaan pada perusahaan yang termasuk kedalam Badan Usaha Milik Negara (BUMN) yang terdaftar di Bursa Efek Indonesia (BEI) tahun 2010-2018, karena BUMN merupakan salah satu perusahaan yang menjadi contoh penerapan kebijakan pemerintah, terutama dalam melaksanakan penerapan tata kelola perusahaan yang baik (Rimardhani, 2016) dan (Peraturan Menteri Negara BUMN Nomor: PER01/MBU/2011).

\section{REVIEW LITERATUR DAN HIPOTESIS}

\section{Landasan Teori}

\section{Teori Agensi}

Teori keagenan (agency theory) pertama kali dikemukakan pada tahun 1976 oleh Michael C. Jensen dan 
William H. Meckling. Teori ini membahas mengenai hubungan yang terjalin di antara pemegang saham (pemilik perusahaan) dengan manajer perusahaan. Manajer diberikan tanggung jawab oleh pemilik perusahaan dalam pengambilan keputusan (Rimardhani, 2016).

Teori keagenan digunakan ketika secara kontraktual telah terjadi hubungan antara pemilik dengan manajer. Pemilik perusahaan tidak bisa mengelola perusahaannya sendiri, sehingga memberikan tanggung jawab mengenai operasional perusahaan kepada seorang manajer.

\section{Komposisi Pengelola Perusahaan}

Setiap perusahaan memiliki komposisi pengelola yang berfungsi untuk mengelola dan menjalankan usahanya agar tujuan perusahan bisa tercapai. Komposisi pengelola tersebut memiliki tugas dan tanggujawab yang berbeda, dengan tujuan bisa memberikan kemajuan terhadap kinerja keuangan perusahaan. Agar komposisi pengelola perusahaan tersebut bisa berjalan dengan baik, maka perusahaan menerapkan tata kelola perusahaan yang baik. Tata kelola perusahaan yang baik merupakan salah satu prinsip yang mendasari mekanisme atau proses pengelolaan pada suatu perusahaan berdasarkan pada etika berusaha dan peraturan pemerintah yang berlaku (Peraturan Menteri Negara BUMN Nomor: PER-01/MBU/2011).

Tata kelola perusahaan diartikan sebagai struktur atau proses yang diterapkan oleh perusahaan untuk menjalankan usahanya, bertujuan meningkatkan nilai dari pemegang saham, namun tetap dengan memperhatikan kepentingan dari stakeholders (Sarafina, 2017). Dalam Peraturan Menteri Negara BUMN Nomor Per-01/MBU/2011 Pasal 3 terdapat beberapa prinsip dasar tata kelola perusahaan di antaranya transparansi, akuntabilitas, tanggungjawab, kewajaran dan kesetaraan. Dalam penelitian ini komposisi pengelolaan perusahaan diproksikan dengan ukuran jumlah komisaris independen, dewan komisaris, dan dewan direksi.

\section{Kinerja Keuangan}

Kinerja keuangan merupakan usaha yang dilakukan perusahaan untuk mengetahui dan mengukur keberhasilan dari perusahaan tersebut dalam menghasilkan laba, sehingga bisa dilihat sejauh mana potensi pertumbuhan dan perkembangan dari perusahaan tersebut (Nabilah, 2018). Penelitian yang dilakukan Sarafina (2017) menjelaskan bahwa kinerja keuangan menjadi patokan utama yang bisa digunakan untuk mengukur serta mengetahui baik atau tidaknya kinerja keuangan pada suatu perusahaan.

Studi yang dilakukan Riandi (2011) menyatakan bahwa tujuan investor atau calon investor berinvestasi yaitu untuk mendapatkan return, apabila return yang diharapkan berasal dari kegiatan normal yang dilakukan perusahaan, maka baik itu investor ataupun calon investor cenderung akan menilai profitabilitas pada perusahaan. Profitabilitas adalah rasio keuangan yang digunakan untuk menilai kemampuan dari suatu perusahaan dalam mencari keuntungan. Profitabilitas dapat digunakan oleh perusahaan sebagai salah satu alat evaluasi terhadap sistem pengelolaan pada suatu badan usaha (Hermuningsih, 2012).

\section{Hipotesis}

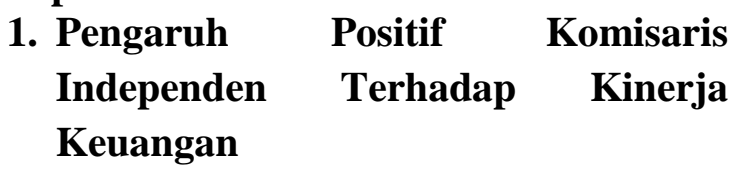


Konflik kepentingan yang terjadi di antara agen dan principal menurut teori keagenan bisa dikurangi dengan adanya pengawasan yang tepat. Pengawasan tersebut dilakukan oleh komisaris independen (Sarafina, 2017). Semakin besar proporsi komisaris independen pada perusahaan, maka akan menunjukkan bahwa fungsi dari pengawasan yang dilakukan sudah lebih baik. Selain itu, dengan adanya pengawasan yang baik dapat meningkatkan kinerja keuangan pada perusahaan (Sarafina, 2017).

Pengawasan yang dilakukan oleh komisaris independen menunjukkan bahwa tujuan dari dibentuknya komisaris independen berjalan dengan baik. Semakin baik kinerja komisaris independen, maka akan semakin baik juga kinerja keuangan pada perusahaan. Komisaris independen dapat meningkatkan efektifitas pengawasan dan meningkatkan kinerja keuangan. Oleh sebab itu, komisaris independen memiliki pengaruh signifikan dalam meningkatkan kinerja keuangan (Fitria, 2018).

Penelitian yang dilakukan oleh Hervita (2015), Widiyawati, (2017), Putri (2016), dan Fitria (2018) menunjukkan hasil bahwa komisaris independen memiliki pengaruh positif dan signifikan terhadap kinerja keuangan. Berdasarkan uraian di atas, maka diperoleh hipotesis sebagai berikut:
H1: Komisaris
Independen
Berpengaruh Positif Terhadap Kinerja Keuangan.

\section{Pengaruh Positif Dewan Komisaris Terhadap Kinerja Keuangan}

Dewan komisaris memiliki tanggung jawab untuk mengawasi proses berlangsungnya proses pelaporan keuangan dan menilai kualitas dari penerapan tata kelola perusahaan. Dewan komisaris memiliki peran penting dalam mengawasi dan memonitoring manajemen pada suatu perusahaan. Semakin besar peningkatan dewan komisaris akan mempengaruhi kinerja keuangan perusahaan (Aprianingsih, 2016).

Dewan komisaris memberikan kontribusi pada peningkatan kinerja keuangan perusahaan. Dewan komisaris ditunjuk untuk mewakili pemegang saham dalam melakukan pengawasan operasional pada badan usaha (Putri, 2018). Studi terdahulu yang dilakukan oleh Widiyawati (2017) dan Kusumawati (2005) menunjukkan bahwa dewan komisaris terbukti berpengaruh terhadap kinerja perusahaan secara positif dan signifikan. Berdasarkan uraian di atas, maka diperoleh hipotesis sebagai berikut:

H2: Dewan Komisaris Berpengaruh Positif Terhadap Kinerja Keuangan.

\section{Pengaruh Positif Dewan Direksi Terhadap Kinerja Keuangan}

Pengelolaan perusahaan bergantung pada kinerja dan kebijakan dari dewan direksi. Tanggung jawab dan tugas yang dimiliki oleh setiap anggota direksi saling berkaitan dan mengikat serta merupakan tanggung jawab sesama anggota direksi pada perusahaan (Rimardhani, 2016). Dewan direksi dapat menentukan kebijakan apa yang harus dan akan diambil serta strategi apa yang bisa dilakukan olehperusahaan baik itu dalam jangka pendek maupun jangka panjang (Sam'ani, 2008).

Penelitian yang dilakukan oleh Hapsoro (2008), Widiwayati (2017), dan Hervita (2015) menunjukan dewan direksi berpengaruh secara positif dan signifikan kinerja keuangan. Berdasarkan uraian di atas, maka diperoleh hipotesis sebagai berikut: 
H3: Dewan Direksi Berpengaruh Positif Terhadap Kinerja Keuangan.

\section{Komisaris Independen, Dewan} Komisaris, dan Dewan Direksi Berpengaruh Secara Simultan Terhadap Kinerja Keuangan

Komposisi pengelola perusahaan diproksikan menggunakan komisaris independen, dewan komisaris, dan dewan direksi sebagai varaibel independen dapat mempengaruhi kinerja keuangan yang diukur dengan variabel Return On Invesment (ROI) sebagai variabel dependen.

H4: Komisaris Independen, Dewan Komisaris dan Dewan Direksi Secara Simultan Berpengaruh Signifikan Terhadap Kinerja Keuangan.

\section{Model Penelitian}

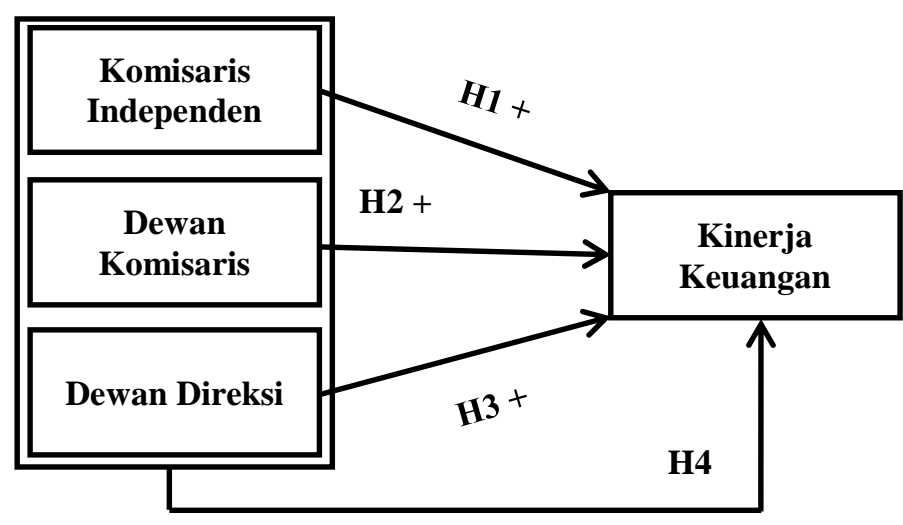

Gambar 1. Model Penelitian sampling, menggunakanpertimbangan dengan (Riandi, 2011).

Pertimbangan yang dilakukan di antaranya: (1) merupakan perusahaan yang termasuk kedalam Badan Usaha Milik Negara (BUMN) yang terdaftar di BEI dan menerbitkan laporan keuangan lengkap dari tahun 2010-2018; (2) menerbitkan laporan keuangan lengkap dari tahun 2010-2018; (3) informasi yang terdapat dalam laporan tahunan dan merupakan laporan keuangan yang sudah di audit, mencakup seluruh variabel yang diperlukan saat melakukan penelitian. Berdasarkan kriteria tersebut, maka sampel yang diambil dalam penelitian ini sebanyak 8 perusahaan yang terbagi menjadi 4 sektor seperti yang terdapat dalam tabel 1 .

\section{Tabel 1. Daftar Sampel Penelitian}

\begin{tabular}{|c|c|c|}
\hline Kode & Nama Perusahaan & Sektor \\
\hline INAF & PT Indofarma Tbk & Farmasi \\
\hline KAEF & $\begin{array}{c}\text { PT Kimia Farma } \\
\text { Tbk }\end{array}$ & Farmasi \\
\hline ADHI & $\begin{array}{c}\text { PT Adhi Karya } \\
\text { Tbk }\end{array}$ & Konstruksi \\
\hline PTPP & PT PP Tbk & Konstruksi \\
\hline WIKA & $\begin{array}{c}\text { PT Wijaya Karya } \\
\text { Tbk }\end{array}$ & Konstruksi \\
\hline WSKT & $\begin{array}{c}\text { PT Waskita Karya } \\
\text { Tbk }\end{array}$ & Konstruksi \\
\hline TINS & PT Timah Tbk & Pertambangan \\
\hline JSMR & PT Jasa Marga Tbk & Transportasi \\
\hline
\end{tabular}

Sumber: Bursa Efek Indonesia (2018)

\section{Variabel Penelitian}

\section{Variabel Dependen}

Return on Investment (ROI) yaitu kemampuan dari perusahaan untuk menghasilkan keuntungan yang nantinya digunakan untuk menutup seluruh investasi yang dikeluarkan (Pradita, 2009). Formula yang digunakan menghitung nilai ROI, sebagai berikut:

$$
\text { ROI }=\frac{\text { Laba Bersih Setelah Pajak }}{\text { Total Aktiva }} \times 100 \%
$$




\section{Variabel Independen}

\section{a. Komisaris Independen}

\section{Komisaris}

independen

memiliki tugas dan tanggung untuk mendorong diterapkannya prinsip tata kelola perusahaan yang baik pada suatu perusahaan. Hal ini dilakukan untuk mendorong anggota lainnya agar bisa melakukan pengawasan dan memberi nasihat pada para direktur secara efektif dengan harapan bisa memberi nilai tambah bagi perusahaan tersebut (Putri, 2016). Variabel komisaris independen dapat diukur dari persentase total komisaris independen terhadap seluruh anggota dewan komisaris (Aprianingsih, 2016).

$$
\mathrm{KI}=\frac{\text { Komisaris Independen }}{\text { Total Komisaris }}
$$

\section{b. Dewan Komisaris}

Dewan komisaris adalah dewan yang memiliki peran sebagai pengawas jalannya kegiatan suatu perusahaan sesuai dengan prinsip tata kelola perusahaan, mengawasi pengambilan keputusan yang dilakukan oleh perusahaan (Aprianingsih, 2016). Dewan komisaris dapat diukur dengan ukuran jumlah dari anggota dewan komisaris yang ada pada suatu perusahaan.

\section{c. Dewan Direksi}

Dewan direksi merupakan seorang pemimpin perusahaan yang memiliki wewenang serta tanggung jawab untuk mengelola suatu perusahaan (Aprianingsih, 2016). Dewan direksi dapat diukur dengan ukuran jumlah anggota dewan direksi yang berada didalam suatu perusahaan.

\section{Analisis Data}

\section{Uji Statistik Deskriptif}

Statistik deskriptif memberikan gambaran dari suatu data yang dilihat dari nilai rata-rata (mean), standar deviasi, varian, maksimum, minimum, sum, range, kurtosis, dan skewness (kemencangan distribusi). Statistik deskriptif digunakan untuk mengembangkan profil perusahaan yang menjadi sampel (Ghozali, 2018).

\section{Uji Asumsi Klasik}

\section{a. Normalitas}

Uji normalitas dilakukan untuk mengetahui di dalam model regresi terdapat variabel yang mengganggu atau mengetahui residual tersebut distribusi normal atau tidak (Noviawan, 2013). Jika nilai sig > 0,05 , maka data tersebut dinyatakan berdistribusi normal dan jika nilai sig $<0,05$, maka data tersebut dinyatakan tidak berdistribusi normal.

\section{b. Autokorelasi}

Tujuan dilakukannya uji autokorelasi yaitu untuk mengetahui di dalam model regresi linear terjadi hubungan antara kesalahan pengganggu pada periode $\mathrm{t}$ dengan kesalahan penganggu pada periode t1 sebelumnya (Ghozali, 2018). Untuk mendeteksi autokorelasi yaitu dengan menggunakan Run Test. Autokorelasi tidak terjadi apabila nilai signifikansi di atas 0,05 atau $5 \%$.

\section{c. Heteroskedastisitas}

Pengujian ini dilakukan untuk mengetahui ketidaksamaan di antara variance residual satu ke pengamatan lainnya dalam model regresi (Sam'ani, 2008). Untuk menguji heteroskedastisitas, peneliti menggunakan uji park dengan melihat nilai signifikansi sebesar 0,05 atau 5\% (Ghozali, 2018). 


\section{d. Multikolinieritas}

Uji multikolinearitas dilakukan dengan tujuan untuk mengetahui masing-masing dari variabel independen saling berhubungan secara linear (Sam'ani, 2008). Multikolinearitas tidak terjadi apabila nilai Tolerance berada di atas 0,1 dan nilai VIF di bawah 10 (Rimardhani, 2016).

\section{Analisis Regresi Linier Berganda}

Analisis regresi dilakukan untuk mengetahui adanya pengaruh dari variabel independen terhadap variabel dependen. Model persamaan pada penelitian ini sebagai berikut:

$$
\mathrm{Y}=\mathbf{a}+\mathbf{b} 1 \mathrm{X} 1+\mathrm{b} 2 \mathrm{X} 2+\mathrm{b} 3 \mathrm{X3}
$$

Keterangan:

Y : ROI

a : Nilai Konstanta

X1 : K I (Komisaris Independen)

X2 : D K (Dewan Komisaris)

X3 : D D (Dewan Direksi)

b1 : Nilai Koefisien X1

b2 : Nilai Koefisien X2

b3 : Nilai Koefisien X3

\section{Uji Hipotesis}

\section{a. Uji Parsial (Uji T)}

Uji t dilakukan dengan tujuan untuk mengetahui variabel independen berpengaruh secara parsial terhadap variabel dependen, dengan tingkat signifikansi kurang dari 0,05 atau 5\% (Ghozali, 2018).

b. Uji Simultan (Uji F)

Uji F dilakukan untuk mengetahui pengaruh variabel independen terhadao variabel dependen secara simultan atau bersama. Uji F dilakukan dengan cara merbandingkan nilai F-hitung dengan F-tabel (Nabilah, 2018). Selain itu bisajuga dengan melihat kolom signifikansi pada tabel anova, apabila tingkat signifikansi kurang dari 0,05 atau 5\% menunjukan bahwa secara bersaman variabel independen berpengaruh terhadap variabel dependen.

\section{Uji Koefisien Determinasi}

Koefisien determinasi $\left(\mathrm{R}^{2}\right)$ digunakan untuk mengukur atau menggambarkan sejauh mana kemampuan dari suatu model bisa menerangkan suatu variasi yang terjadi dalam variabel dependen (Ghozali, 2018).

\section{HASIL PENELITIAN DAN PEMBAHASAN}

\section{Uji Statistik Deskriptif}

Tabel 2. Hasil Uji Statistik Deskriptif

\begin{tabular}{ccccc}
\hline & Min & Max & Mean & $\begin{array}{c}\text { Std. } \\
\text { Deviation }\end{array}$ \\
\hline $\begin{array}{c}\text { Komisaris } \\
\text { Independen } \\
\text { Dewan }\end{array}$ & 0,2000 & 0,6667 & 0,376488 & 0,0691891 \\
$\begin{array}{c}\text { Komisaris } \\
\text { Dewan }\end{array}$ & 3,0000 & 7,0000 & 5,333333 & 0,9786452 \\
$\begin{array}{c}\text { Direksi } \\
\text { Kinerja }\end{array}$ & 3,0000 & 7,0000 & 5,319444 & 0,8853485 \\
$\begin{array}{l}\text { Keuangan } \\
\text { Sumber: Data Sekunder Diolah (2018) }\end{array}$ & 0,0012 & 0,1612 & 0,043731 & 0,0266610 \\
\multicolumn{4}{l}{}
\end{tabular}

Berdasarkan tabel 2 di atas, dapat dilihat bahwa Komisaris Independen mempunyai nilai terendah sebesar 0,200 dan tertinggi 0,666 , nilai rata-rata sebesar 0,376, dengan standar deviasi sebesar 0,069. Dewan Komisaris mempunyai nilai terendah sebesar 3,000 dan tertinggi 7,000, nilai rata-rata sebesar 5,333, dengan standar deviasi sebesar 0,978. Selanjutnya variabel Dewan Direksi mempunyai nilai terendah sebesar 3,000 dan tertinggi 7,000, nilai ratarata sebesar 0,531, dengan standar deviasi sebesar 0,885 . Kinerja Keuangan mempunyai nilai terendah adalah 0,001 dan tertinggi 0,161 , nilai rata-rata sebesar 0,437, dengan standar deviasi sebesar 0,266 . 
Uji Asumsi Klasik

1. Normalitas

Tabel 3. Hasil Uji Normalitas

\begin{tabular}{lr}
\hline & $\begin{array}{c}\text { Unstandardized } \\
\text { Residual }\end{array}$ \\
\hline Kolmogorov-Smirnov Z & 1,018 \\
Asymp. Sig. (2-tailed) & 0,252 \\
\hline
\end{tabular}

Sumber: Data Sekunder Diolah (2018)

Berdasarkan hasil analisis, dapat dilihat nilai Kolmogrov-Smirnov sebesar 1,018 dengan nilai signifikansi sebesar $0,252>0,05$, sehingga nilai tersebut menunjukkan bahwa data penelitian yang digunakan sudah terdistribusi normal karena nilai Asymp. Sig. (2tailed) di atas 0,05 atau $5 \%$.

\section{Autokorelasi}

\section{Tabel 4. Hasil Uji Autokorelasi}

\begin{tabular}{lr}
\hline & $\begin{array}{c}\text { Unstandardized } \\
\text { Residual }\end{array}$ \\
\hline Test Value $^{\mathrm{a}}$ & $-0,00442$ \\
Asymp. Sig. (2-tailed) $^{\text {As }}$ & 0,342 \\
\hline
\end{tabular}

Sumber: Data Sekunder Diolah (2018)

Hasil output tabel 4 di atas menunjukkan bahwa nilai test adalah sebesar -0,00442 dengan nilai Asymp. Sig. (2-tailed) menunjukkan nilai 0,342 lebih besar dari 0,05, maka dapat disimpulkan bahwa data tersebut tidak terjadi masalah autokorelasi.

\section{Heteroskedastisitas}

Tabel 5. Hasil Uji Heteroskedastisitas

\begin{tabular}{llrl}
\hline \multicolumn{2}{l}{ Model } & \multicolumn{1}{c}{$\mathrm{t}$} & Sig. \\
\hline 1 & (Constant) & $-1,965$ & 0,054 \\
& Komisaris Independen & 1,977 & 0,052 \\
& Dewan Komisaris & 0,284 & 0,777 \\
& Dewan Direksi & $-1,017$ & 0,313
\end{tabular}

Sumber: Data Sekunder Diolah (2018)

Tabel 5 di atas menunjukkan hasil bahwa nilai signifikan dari semua variabel independen berada di atas 0,05. Dengan demikian dapat disimpulkan bahwa model regresi tersebut tidak mengandung atau tidak terjadi heterokedastisitas.
4. Multikolinieritas

Tabel 6. Hasil Uji Multikolinieritas

\begin{tabular}{llrr}
\hline Model & \multicolumn{2}{c}{ Collinearity Statistics } \\
& & & \\
\hline 1 & (Colerance & VIF \\
\hline & Komisarist) Independen & 0,987 & 1,013 \\
& Dewan Komisaris & 0,389 & 2,572 \\
Dewan Direksi & 0,392 & 2,552
\end{tabular}

Sumber: Data Sekunder Diolah (2018)

Dari tabel 6 di atas berdasarkan pada nilai Tolerance dan VIF, maka terlihat bahwa nilai Tolerance dari semua variabel independen di atas 0,10 (nilai tolerance berkisar antara 0,392 sampai 0,987 ), begitupun dengan nilai VIF berada di bawah 10 (nilai VIF berkisar antara 1,013 sampai 2,552). Sehingga dapat disimpulkan model tersebut terbebas dari gangguan multikolinearitas, atau tidak terjadi multikolinearitas antar variabel independen dalam model regresi.

Analisis Regresi Linier Berganda

\begin{tabular}{|c|c|c|c|c|c|}
\hline \multicolumn{6}{|c|}{ Tabel 7. Hasil Regresi } \\
\hline Variabel & Hipotesis & $\begin{array}{l}\text { Koefisien } \\
\text { Regresi (B) }\end{array}$ & $t$ & Sig. & Keterangan \\
\hline (Constant) & & $\cdot 0,140$ & $\cdot 1,278$ & 0,206 & \\
\hline Komisaris Independen & Positif & 0,270 & 2,210 & 0,030 & Diterima \\
\hline Dewan Komisaris & Positif & 0,107 & 2,292 & 0,025 & Diterima \\
\hline Dewan Dirksi & Positif & $\cdot 0,030$ & $\cdot 0,580$ & 0,564 & Ditolak \\
\hline
\end{tabular}

Sumber: Data Sekunder Diolah (2018)

Berdasarkan hasil analisis pada tabel 7 di atas, maka diperoleh model sebagai berikut:

ROI $=-0,140+0,270 \mathrm{KI}+0,107 \mathrm{DK}-$ 0,030 DD 


\section{Uji Hipotesis}

\section{Uji Parsial (Uji T)}

Tabel 8. Hasil Uji Parsial

\begin{tabular}{lccccc}
\hline \multicolumn{1}{c}{ Variabel } & Hipotesis & $\begin{array}{c}\text { Koefisien } \\
\text { Regresi }(\beta)\end{array}$ & & Sig. & Keterangan \\
& & $\cdot 0,140$ & $\cdot 1,278$ & 0,206 & \\
\hline (Constant) & & 0,270 & 2,210 & 0,030 & Diterima \\
Komisaris Independen & Positif & 0,27 & \\
Dewan Komisaris & Positif & 0,107 & 2,292 & 0,025 & Diterima \\
Dewan Direksi & Positif & $\cdot 0,030$ & $-0,580$ & 0,564 & Ditolak \\
\hline
\end{tabular}

Sumber: Data Sekunder Diolah (2018)

Berikut ini merupakan penjelasan hasil yang diperoleh dari uji parsial:

a. Hipotesis pertama (H1) adalah Komisaris Independen berpengaruh positif terhadap Kinerja Keuangan. Berdasarkan hasil analisa pada tabel 7 di atas, nilai koefisien $=0,270$ dengan nilai signifikansi $0,03<0,05$, dapat disimpulkan bahwa variabel komisaris independen secara parsial berpengaruh positif terhadap kinerja keuangan yang berarti $\mathbf{H 1}$ diterima.

b. Hipotesis kedua (H2) adalah Dewan Komisaris berpengaruh positif terhadap Kinerja Keuangan. Berdasarkan hasil analisis pada tabel 7 di atas, nilai koefisien $=0,107$ dengan nilai signifikansi $0,025<$ 0,05, dapat disimpulkan bahwa variabel dewan komisaris secara parsial berpengaruh positif terhadap kinerja keuangan yang berarti $\mathbf{H 2}$ diterima.

c. Hipotesis ketiga (H3) adalah Dewan Direksi berpengaruh positif terhadap Kinerja Keuangan. Berdasarkan hasil analisis pada tabel 7 di atas, nilai koefisien $=-0,030$ dengan nilai signifikansi $0,564>0,05$, dapat disimpulkan bahwa variabel dewan direksi secara parsial memiliki pengaruh negatif terhadap kinerja keuangan yang berarti $\mathbf{H 3}$ ditolak.

\section{Uji Simultan (Uji F)}

Tabel 9. Hasil Uji Simultan

\begin{tabular}{llll}
\hline Model & F & Sig. \\
\hline 1 & Regression & 4,195 & $0,009^{\mathrm{a}}$ \\
& Residual & & \\
& Total & &
\end{tabular}

Sumber: Data Sekunder Diolah (2018)

Berdasarkan hasil uji simultan pada tabel 9 di atas, menunjukkan bahwa F-hitung sebesar 4,195 > F-tabel 2,470, dengan nilai signifikansi sebesar 0,009< 0,05 . Hasil tersebut menunjukkan bahwa secara bersama-sama variabel komisaris independen, dewan komisaris dan dewan direksi memiliki pengaruh signifikan terhadap kinerja keuangan yang berarti $\mathbf{H 4}$ diterima.

\section{Uji Koefisien Determinasi}

Tabel 10. Hasil Uji Koefisien Determintasi

\begin{tabular}{crr}
\hline Model & R square & Adjusted R Square \\
\hline 1 & 0,156 & 0,119
\end{tabular}

Sumber: Data Sekunder Diolah (2018)

Hasil analisis pada tabel $10 \mathrm{di}$ atas menunjukkan bahwa nilai Adjusted $\mathrm{R}^{2}$ square sebesar 0,119 atau $11,9 \%$. Hal tersebut menunjukkan bahwa variasi ROI dapat dijelaskan oleh komisaris independen, dewan komisaris, dan dewan direksi sebesar $11,9 \%$ dan sisanya $88,1 \%$ dijelaskan oleh variabel lain diluar variabel yang digunakan dalam penelitian ini.

\section{Pembahasan}

\section{Pengaruh Positif Komisaris Independen Terhadap Kinerja Keuangan}

Berdasarkan hasil uji hipotesis pertama yang telah dilakukan, menunjukkan bahwa komisaris independen berpengaruh positif terhadap kinerja keuangan. Dengan demikian hipotesis pertama yang menyatakan bahwa komisaris independen berpengaruh positif 
terhadap kinerja keuangan perusahaan diterima. Hasil penelitian ditunjukkan dengan nilai koefisien 0,270 dan nilai signifikansi sebesar $0,030<0,05$.

Komisaris independen memiliki pengaruh positif terhadap kinerja keuangan dapat dijelaskan bahwa, semakin besarnya proporsi komisaris independen yang berasal dari luar perusahaan dengan keahlian dan pengalaman yang beragam, memungkinkan dapat meningkatkan kemampuan komisaris independen dalam melakukan pengawasan (Sarafina, 2017). Pengawasan tersebut mampu mempengaruhi perilaku manajer dalam upaya meningkatkan kinerja perusahaan (Maryanah, 2011). Semakin besar komisaris independen, maka pengawasan terhadap manajemen perusahaan akan semakin baik, sehingga akan meningkatkan kinerja keuangan (Maryanah, 2011).

Pengawasan yang dilakukan oleh komisaris independen menunjukkan bahwa tujuan dibentuknya komisaris independen dalam suatu perusahaan sudah berjalan dengan baik dan berhasil menigkatkan kinerja keuangan. Komisaris independen dapat meningkatkan efektifitas pengawasan dan meningkatkan Kinerja Keuangan. Oleh sebab itu, komisaris independen memiliki pengaruh dalam meningkatkan Kinerja Keuangan (Fitria, 2018). Penelitian ini sejalan dengan penelitian yang dilakukan oleh Hapsoro (2008), Maryanah (2011), Hervita (2015), Putri (2016), dan Fitria (2018).

\section{Pengaruh Positif Dewan Komisaris Terhadap Kinerja Keuangan}
Berdasarkan hasil uji hipotesis kedua yang telah dilakukan, menunjukkan bahwa dewan komisaris berpengaruh positif terhadap kinerja keuangan. Dengan demikian hipotesis yang menyatakan bahwa dewan komisaris berpengaruh positif terhadap

kinerja keuangan perusahaan diterima. Hasil penelitian ditunjukkan dengan nilai koefisien 0,107 dan nilai signifikansi sebesar $0,025<0,05$.

Dewan komisaris memiliki pengaruh terhadap kinerja keuangan, sehingga dapat diartikan bahwa dengan semakin besarnya peningkatan dewan komisaris, maka akan mempengaruhi kinerja keuangan perusahaan. Dewan komisaris diperkirakan dapat memberikan kontribusi pada peningkatan kinerja keuangan perusahaan.

Dewan komisaris ditunjuk untuk mewakili pemegang saham dalam melakukan pengawasan operasional pada badan usaha (Putri, 2018). Lebih lanjut Putri (2018) menyatakan bahwa peningkatan jumlah komisaris akan menyebabkan adanya pengawasan lebih ketat terhadap pihak manajer, sehingga manajer bisa lebih giat dalam meningkatkan performa perusahaan dan kemungkinan terjadinya penyelewengan terhadap perusahaan menjadi semakin rendah. Dewan komisaris yang lebih besar diperkirakan mampu menstimulus pertukaran pengetahuan dan informasi antar anggota dewan komisaris (Putri, 2018). Adanya transfer pengetahuan dan informasi tersebut dewan komisaris lebih mengetahui kondisi perusahaan dan iklim industri yang tengah dihadapi oleh perusahaan, sehingga dapat menghasilkan keputusan yang efektif. Penelitian ini sejalan dengan penelitian yang dilakukan oleh Widagdo (2014), Adestian (2015), dan Widiyawati (2017).

\section{Pengaruh Positif Dewan Direksi Terhadap Kinerja Keuangan}

Berdasarkan hasil uji hipotesis ketiga yang telah dilakukan, menunjukkan bahwa dewan direksi berpengaruh negatif terhadap kinerja keuangan. Dengan demikian hipotesis 
yang menyatakan bahwa dewan direksi berpengaruh positif terhadap kinerja keuangan perusahaan ditolak. Hasil penelitian ditunjukkan dengan nilai koefisien $-0,030$ dan nilai signifikansi sebesar 0,564>0,05.

Studi yang dilakukan oleh Rimardhani (2016) menyatakan bahwa jumlah dewan direksi dalam perusahaan tidak dapat mempengaruhi besar kecilnya kinerja keuangan. Dewan direksi diperkirakan belum mampu melakukan koordinasi serta pengambilan keputusan yang tepat dalam menjalankan fungsi kontrol yang lebih baik untuk meningkatkan profitabilitas pada perusahaan.

Semakin besar jumlah dewan direksi berkaitan dengan dua hal, yaitu meningkatnya permasalahan dalam hal komunikasi dan koordinasi, serta dengan semakin besar jumlah dewan yang ada, pengawasan juga akan semakin sulit, sehingga menimbulkan permasalahan agensi yang muncul dari pemisahan antara manajemen dan control (Bukhori, 2012). Penelitian ini sejalan dengan penelitian yang dilakukan oleh Bukhori (2012), Widagdo (2014), Rimardhani (2016), dan Widyastuti (2017).

\section{Pengaruh Komisaris Independen, Dewan Komisaris, dan Dewan Direksi Secara Simultan Terhadap Kinerja Keuangan}

Hasil penelitian ini menunjukkan bahwa variabel komisaris independen, dewan komisaris, dan dewan direksi secara bersama-sama berpengaruh signifikan terhadap kinerja keuangan. Hasil perhitungan menunjukkan nilai Fhitung 4,195 > F-tabel 2,740 dan nilai signifikansi sebesar 0,009 $<0,05$.

Fitria (2018) menyatakan bahwa dengan adanya tata kelola perusahaan yang baik, akan menciptakan iklim usaha yang sehat dan mendorong peningkatan kinerja perusahaan itu sendiri. Secara teoritis, pelaksanaan tata kelola perusahaan yang baik dapat meningkatkan nilai perusahaan dengan meningkatkan kinerja keuangan (Paradita, 2009). Adanya penerapan tata kelola perusahaan yang baik akan meningkatkan kinerja keuangan, mengurangi risiko akibat tindakan pengelolaan yang cenderung menguntungkan diri sendiri dan mencegah terjadinya kecurangan (Fitria, 2018). Penelitian ini sejalan dengan penelitian yang dilakukan oleh Ferdiana (2012), Prasinta (2012), dan Khumairoh (2014).

\section{KESIMPULAN DAN SARAN}

\section{Kesimpulan}

Berdasarkan penelitian yang telah dilakukan, hasil penelitian menunjukkan bahwa secara parsial komisaris independen dan dewan komisaris memiliki pengaruh positif terhadap kinerja keuangan. Sementara dewan direksi memiliki pengaruh negatif terhadap kinerja keuangan. Secara simultan variabel komisaris independen, dewan komisaris, dan dewan direksi memiliki pengaruh signifikan terhadap kinerja keuangan. Nilai r-square pada persamaan regresi yaitu sebesar 0,119 atau 11,9\%. Hal ini menunjukkan bahwa kinerja keuangan hanya dapat dijelaskan oleh komisaris independen, dewan komisaris, dan dewan direksi sebesar $11,9 \%$ dan sisanya $88,1 \%$ dipengaruhi variabel lain yang tidak diuji dalam penelitian ini.

\section{Saran}

Adapun saran yang dapat diberikan oleh peneliti di antaranya, bagi perusahaan baik itu perusahaan BUMN maupun perusahaan swasta diharapkan bisa melaksanakan penerapan dari tata kelola perusahaan dengan baik, agar investor 
tertarik untuk melakukan investasi. Dalam memutuskan investasi pada suatu perusahaan investor haruslah bijaksana. Investor sebaiknya mempertimbangankan berbagai aspek sebelum melakukan investasi terutama dalam pelaksanaan dan penerapan dari tata kelola perusahaan yang baik, karena dengan terlaksananya tata kelola perusahaan yang baik maka hak dari investor pada perusahaan tersebut akan terlindungi.

Peneliti selanjutnya diharapkan bisa melakukan penelitian serupa dengan menambahkan variabel indikator lainnya untuk mengukur pengaruh dari penerapan tata kelola perusahaan yang baik terhadap kinerja keuangan, menambah jumlah sampel dan tahun, sehingga tidak hanya perusahaan BUMN saja tetapi mencakup ruang lingkup yang lebih luas, misalnya perusahaan pada sektor lain yang terdaftar di Bursa Efek Indonesia (BEI).

\section{DAFTAR PUSTAKA}

Adestian, Y. (2015). Pengaruh Dewan Komisaris, Dewan Direksi, Dewan Komisaris Independen, Komite Audit dan Ukuran Perusahaan Pada Kinerja Perusahaan Perbankan Yang Listing Di BEI Pada Tahun 20122014. Jurnal Ekonomi Dan Bisnis.

Aprianingsih, A., \& Yushita, A. N. (2016). Pengaruh Penerapan Good CorporateGovernance, Struktur Kepemilikan, Dan Ukuran Perusahaan Terhadap Kinerja Keuangan Perbankan. Jurnal Profita: Kajian Ilmu Akuntansi, 4(4).

Bukhori, I., dan Raharja, R. (2012). Pengaruh good corporate governance dan ukuran perusahaan terhadap kinerja perusahaan (studi empiris pada perusahaan yang terdaftar di
BEI 2010). Doctoral dissertation, Fakultas Ekonomika dan Bisnis.

Ferdiana, N. (2012). Pengaruh Good Corporate Governance Terhadap Kinerja Keuangan Perusahaan Pertambangan di BEI. Jurnal Ilmiah Mahasiswa Akuntansi, 1(2).

Fitria, Risma Lindia dan Amanita Novi Yushita. (2018). Pengaruh Good Coporate Governance (GCG) Dan Capital Adequacy Ratio (CAR) Terhadap Kinerja Keuangan Perbankan Yang Terdaftar Di Bursa Efek Indonesia Periode 2013-2015. Profia: Kajian Ilmu Akuntansi, Vol. 6, No. 4.

Ghozali, Imam. (2018). Aplikasi Analisis Multivariate dengan Program SPSS. Edisi Kesembilan. Semarang: Badan Penerbit Universitas Diponegoro.

Hapsoro, D. (2008). Pengaruh mekanisme corporate governance terhadap kinerja perusahaan : Studi empiris di pasar modal Indonesia. Jurnal Akuntansi dan Manajemen, 19(3).

Hermuningsih, S. (2012). Pengaruh profitabilitas, size terhadap nilai perusahaan dengan sruktur modal sebagai variabel intervening. Jurnal Fakultas Hukum UII, 16(2).

Hervita, Kriswanto. (2015). Pengaruh Good Corporate Governance Terhadap Net Propit Margin dan Return Saham Perusahaan yang Termasuk Pemeringkatan ASEAN CG Scorecard Tahun 2014. Doctoral dissertation, BINUS.

Kementerian BUMN. (2011). Peraturan Menteri BUMN PER-01/MBU/2011 tanggal 01 Agustus 2011 Tentang Penerapan Tata Kelola Perusahaan Yang Baik (Good Corporate 
Governance) Pada BUMN. Jakarta : Kementerian BUMN. (http://jdih.bumn.go.id/lihat/PER01/MBU/2011 diakses pada tanggal 01 Oktober 2018).

Khumairoh, N. D., Sambharakreshna, Y. dan Kompyurini, N. (2014). Pengaruh Kualitas Good Corporate Governance Terhadap Nilai Perusahaan dengan Kinerja Keuangan Sebagai Variabel Intervening. Journal of Auditing, Finance, and Forensic Accounting, 2(1).

Kusumawati, D. N. dan Riyanto, B. (2005). Corporate governance dan kinerja: analisis pengaruh compliance reporting dan struktur dewan terhadap kinerja. Simposium Nasional Akuntansi, 8.

Maryanah dan Amilin. (2011). Pengaruh Corporate Governance dan Kepemilikan Manajerial Terhadap Kinerja Perusahaan (Studi Pada Perusahaan yang Terdaftar di Bursa Efek Jakarta). Jurnal Akuntabilitas.

Nabilah, Zahrah. (2018). Pengaruh Good Corporate Governance Terhadap Nilai Perusahaan Dengan Kinerja Keuangan Sebagai Variabel Intervening Pada Perusahaan yang Terdaftar Dalam Indeks LQ45 Bursa Efek Indonesia Tahun 2010-2016. Yogyakarta: Universitas Sarjanawijaya Tamansiswa.

Noviawan, R. A., \& Septiani, A. (2013). Pengaruh Mekanisme Corporate Governance dan Struktur Kepemilikan terhadap Kinerja Keuangan. Doctoral Dissertation. Fakultas Ekonomika dan Bisnis.

Riandi, D., \& Siregar, H. S. (2011). Pengaruh penerapan good corporate governance terhadap return on asset, net profit margin, dan earning per share pada perusahaan yang terdaftar di corporate governance perception index.

Rimardhani, H., \& Hidayat, R. R. (2016). Pengaruh Mekanisme Good Corporate Governance Terhadap Profitabilitas Perusahaan (Studi Pada Perusahaan BUMN Yang Terdaftar di BEI Tahun 2012-2014). Jurnal Administrasi Bisnis, 31(1).

Sam'ani. (2008). Pengaruh Good Corporate Governance Dan Leverage Terhadap Kinerja Keuangan Pada Perbankan yang Terdaftar di Bursa Efek Indonesia (BEI) Tahun 2004- 2007. Tesis Tidak Dipublikasikan. Magister Manjemen, Universitas Diponegoro Semarang.

Sarafina, S., \& Saifi, M. (2017). Pengaruh Good Corporate Governance terhadap Kinerja Keuangan dan Nilai Perusahaan (Studi pada Badan Usaha Milik Negara (BUMN) yang Terdaftar di Bursa Efek Indonesia Periode 2012-2015). Jurnal Administrasi Bisnis, 50(3).

Utami, Nurina. (2012). Pengaruh Good Corpotare Governance Terhadap Kinerja Keuangan pada Perusahaan yang Terdaftar di Corporate Governance Perception Index (CGPI). Jurnal Akuntansi.

Paradita, D. (2009). Pengaruh Good Corporate Governance terhadap Kinerja Keuangan pada Perusahaan yang Termasuk Kelompok Sepuluh Besar menurut Corporate Governance Perception Index (CGPI). Skripsi Akuntansi. Medan: Universitas Sumatera Utara. 
Pradita, Alam. (2009). Analisis Potensi Pengembangan Pajak Hotel di Kabupaten Semarang. Skripsi Tidak Dipublikasikan. Fakultan Ekonomi Universitas Diponegoro Semarang.

Prasinta, D. (2012). Pengaruh good corporate governance terhadap kinerja keuangan. Accounting Analysis Journal, 1(2).

Putri, D. S. K. (2016). Pengaruh Penerapan Good Corporate Governance Terhadap Kinerja Keuangan Studi Empiris Pada Perusahaan Perbankan yang Terdaftar Di BEI Tahun 20102014. Doctoral Dissertation. Universitas Muhammadiyah Surakarta.

Putri, R. A. (2018). Pengaruh Good Corporate Governance Terhadap Kinerja Keuangan (Studi Empiris Perusahaan Makanan dan Minuman di Bursa Efek Indonesia Periode 2014-2016). Doctoral Dissertation. Universitas Muhammadiyah Surakarta.

Widagdo, D. O. K. dan Chariri, A. (2014). Pengaruh Good Corporate Governance Terhadap Kinerja Perusahaan (Studi Empiris Pada Perusahaan nonfinancial yang Terdaftar di Bursa Efek Indonesia). Doctoral dissertation, Fakultas Ekonomika dan Bisnis.

Widiyawati, L., Raharjo, K., \& Oemar, A. (2017). Effect Of Implementation Of Good Corporate Governance (GCG) To Return On Assets (ROA), Return On Equity (ROE), Earning Per Share (EPS) and Net Profit Margin (NPM) (Studies in Banking Companies Listed on the Stock Exchange Year 2011 to 2015). Journal of Accounting, 3(3). 